\title{
Trouble Ahead: The Cocaleros of Peru'
}

\author{
VANDA FELBAB-BROWN ${ }^{2}$ \\ Vanda_Felbab-Brown@Kgs.harvard.edu \\ vfelbab@mit.edu
}

\begin{abstract}
Artículo recibido 10/03/2006
Evaluación par externo 25/05/2006

Evaluación par interno 20/05/2006
\end{abstract}

\begin{abstract}
Resumen
El efecto de una política antinarcóticos que ignora las consecuencias de la erradicación de cultivos de coca es radicalizar y aislar aún más la población en aquellas zonas donde prosperan la anarquia y el terrorismo. Además, fortalece los lazos entre los descontentos sociales y los grupos guerrilleros en esas mismas áreas. Washington no puede seguir ciega al hecho de que las tres politicas actuales de Estados Unidos —antiterrorismo, antinarcóticos y democratización en el Perú y otras regiones en América Latina- no están funcionando armónicamente. Resulta paradójico que la erradicación de cultivos de coca -eje de la política antinarcóticos peruana respaldada por Estados Unidos- ensanche las bolsas de miseria y aliente la ira contra el gobierno, además de perpetuar los proverbiales miasmas de marginación en las que se engendra el terrorismo. En vez de fortalecer al Estado, la erradicación
\end{abstract}

\footnotetext{
${ }^{1}$ Este artículo es una versión reducida del original publicado en la Revista Current History, Vol. 105, No. 688, febrero, 2006, pp. 79-86. La revista Desafíos ha decidido publicar apartes por considerarlo de interés para la discusión sobre los efectos y resultados de la política de erradicación de cultivos ilícitos en Colombia. - This article is an abbreviated reproduction of the article published in the Current History Journal, Vol. 105, Nr. 688, Februrary, 2006, pp. 79-86. Desafíos Journal decided to publish parts of it due to the consideration of its interest for the discussion on consequences and results of the eradication policy of ilegal crops in Colombia.

${ }^{2}$ VANDA FELBAB-BROWN is a fellow at the Belfer Center for Science and International Affairs, John F. Kennedy School of Government, Harvard University.
} 
Trouble Ahead: The Cocaleros of Peru/ 305

de cultivos de coca, tal y como se está llevando a cabo en los países andinos, incrementa las posibilidades de su fracaso.

Palabras clave: Política antinarcóticos, pobreza, terrorismo, fracaso del Estado, paises andinos.

\begin{abstract}
An anti-narcotics policy that ignores the social consequences of drug crops eradication only manages to further radicalize and isolate the population in areas in which lawlessness and potential terrorist activity thrive. It also strengthens the bond between disaffected social groups and guerrilla organizations in these areas. Washington cannot continue to be blind to the fact that the three current US policies on counterterrorism, anti-narcotics, and democratization in Peru and elsewhere in Latin America, are not working in harmony. Paradoxically, the eradication of drug crops — the core of Peru's US-sponsored anti-narcotics policy - enlarges pockets of poverty and fuels anger against the government. It also perpetuates the proverbial quagmire of alienation in which terrorism breeds. Instead of strengthening the State, drug eradication, particularly in the way it is currently carried out in the Andean countries, increases the risk of State failure.
\end{abstract}

Key words: anti-narcotics policy, poverty, terrorism, state failure, Andean countries.

Desafíos, Bogotá (Colombia), (14): 304-317, semestre I de 2006

9. Vanda Felba.p65 
If the social protests that paralyzed parts of Peru during the summer of 2005 were taking place elsewhere -Lebanon, Georgia, or Venezuela, for example- the United States might well be celebrating them as civil society on the march toward democracy. And the Bush administration probably would be hailing Nancy Obregón and Elsa Malpartida, the two university-educated women at the forefront of the agitation, as paragons of women's empowerment, exemplifying the close connection between democratization and women's rights.

Instead, both Lima and Washington disparage the civil protests as a conspiracy of drug dealers and narco-farmers attempting to subvert the US-sponsored eradication of coca. And the two women are scorned as trouble-fomenting radicals. This clash between America's posture of promoting democratic movements "global" and its counternarcotics policies in Peru is embarrassing enough. Potentially more dangerous to US security is the way the counternarcotics strategy undermines US grand strategy for combating terrorism, which includes efforts to buttress the legitimacy and capacity of states in developing countries to provide security as well as the rudiments of justice and public order.

Paradoxically, the eradication of drug crops -the centerpiece of Peru's US-sponsored counternarcotics policy- enlarges pockets of poverty and fuels anger with the government. It also perpetuates the proverbial swamps of alienation in which terrorism breeds. Instead of strengthening the state, drug eradication, the way it is currently conducted in the Andean countries, increases the risk of state failure.

\section{Drug dealers' civil society}

Although striking coca farmers are probably bankrolled to some extent by Peruvian drug dealers, the popular dissatisfaction with eradication is genuine and widespread. Between 300,000 and 500,000 people today are directly dependent on the coca economy in Peru. They have essentially no alternative means of support and face the prospect of dire poverty without the illegal economy. Alternative development programs, which encourage the cultivation 
Trouble Ahead: The Cocaleros of Peru/ 307

of substitute legal crops and promote overall rural development, have largely failed because of years of minimal funding, the shortterm nature of the programs, and their mismanagement.

It is thus hardly surprising that eradication campaigns generate profound alienation. The drug dealers may be funding and shaping the agitation of the coca peasants, but they did not create it. Overwhelming discontent with eradication is the source of the angry protests and the emerging social movement. Ironically, civil society, which the United States has been exporting as a means of democratization around the world, is precisely what is complicating its counternarcotics policies in the Andes.

These complications are likely to grow in Peru since the coca farmers are becoming better organized. They lack the cohesion, party organization, and leadership of their counterparts in Bolivia, where Evo Morales, the head of Movimiento al Socialismo -MAS- was recently elected president. But Peru's farmers have begun to form institutional structures, such as the National Confederation of Agricultural Producers in Peru's Coca Growing Valleys (CONPACCP), that lend greater political power to their movement than unorganized spontaneous riots can achieve.

Lack of unity still undermines the movement's effectiveness, since the four major areas of Peruvian coca production -the Huallaga Valley, the Apurímac-Ene Valley, the Monzón Valley, and the department of Cuzco- have competing interests. Cuzco, which for years has had some legal cultivation of coca for traditional use in addition to ille- "Ironically, civil society, which the United States has been exporting as a means of democratization around the world, is precisely what is complicating its counternarcotics policies in the Andes". Trouble Ahead: The Cocaleros of Peru VANDA FELBAB-BROWN gal cultivation, has never fully embraced its altogether illegal counterparts in the three other production areas. While Cuzco has tried to straddle the boundaries of legality and criminality, the Monzón Valley has gone to the other extreme, not only protecting its illegal economy with arms, but also blocking even the minimal state presence the Pe-

Desafíos, Bogotá (Colombia), (14): 304-317, semestre I de 2006 
ruvian government has attempted to field in that region. No Peruvian policemen, for example, have been present in the Monzón Valley for years. In Monzón the drug barons reign supreme.

Moreover, all four drug production areas would be pleased by the collapse of their competition in the other areas. Their own coca leaf price could then rise and they could capture a greater share of the market. The Monzón Valley coca farmers, for example, did not join the CONPACCP, creating instead an independent organization, the Monzón Valley Association of Agricultural Producers. In fact, the producers and coca-growing technical experts hired by drug dealers in the different valleys are in intense competition over who can achieve greater coca productivity. (So far, Monzón is winning, with up to six harvests of coca leaf a year.) The common threat of eradication, however, is pushing the separate groups together and cementing the bonds among organizations of otherwise competing interests. Not only the fragmentation of the movement, but also the distance of the coca-growing regions from Lima, the capital, reduce the farmers' power as compared to MAS in Bolivia.

Unlike in Bolivia, where the coca-producing regions are close to the capital, the eastern jungles of Peru where coca is grown are far removed from the country's urban coast and south. Because of their remoteness, the historical absence of the state in these areas, and the traditional stratification of Peru into urban and rural classes, the coca eradication issue fails to resonate with many people in the cities. Even those who sympathize in the abstract with the cause of the coca peasants do not like to see their cities -Chiclayo, Cuzco, Arequipa, Puno- blockaded and general strikes shutting down their businesses and hurting tourism. In recent years, however, the cocalero movement has been trying to build bridges to other disgruntled groups, such as anti-mining organizations, environmentalist groups, those who oppose free trade with the United States for fear of not being able to compete with US businesses, and those who oppose increases in mandatory car insurance. Some of these groups do have a strong urban base. 
Most important, the cocalero movement has increasingly good ties with many of the peasant selfdefense groups that fought the Shining Path (Sendero Luminoso) in the early 1990s and that still are armed today. Many of these self-defense groups used the coca trade to finance the acquisition of weapons with which they fought the Maoist guerrillas. Some of the peasant groups directly overlap with the cocalero movement today. And even where there is not a direct overlap, the groups are likely to be sympathetic to the cocalero cause.

\section{Demagogues in the wings}

The diversity of various protest groups' interests and their lack of unity make it possible for the Peruvian government to attempt to play divide-and-conquer, and perhaps coopt some of them. Yet, should the cocalero peasants succeed in cementing their alliance with other disgruntled social organizations, they have the potential to transform their movement into one with a national agenda. And should a Peruvian Evo Morales emerge one day, the movement could achieve enough political power to take over the government in Lima -whether through elections or through the collapse of the Peruvian government because of persistent chaos and social strife.

Meanwhile, the social movement is up for grabs by various political entrepreneurs, many of whom are not particularly savory characters. The Humala brothers' Etno-Caceristas, an ultranationalist fascistlike group, openly defends coca cultivation and has tried to co-opt the movement. So has Peru's far-left Patria Roja. The remnants of the Shining Path -including several hundred armed fighters engaged in occasional terrorist actions- are also among the aspirants to leadership of the coca peasants. Although the Shining Path is unlikely to be able to reconstitute itself to pose a serious threat to the government, an alliance with coca peasants would still be disadvantageous to US counterterrorism and counternarcotics interests.

Not all political entrepreneurs who attempt to co-opt this growing political force in Peru represent the extremes of the political

Desafíos, Bogotá (Colombia), (14): 304-317, semestre I de 2006 
spectrum or outright criminality and terrorism. But moderate representatives of the regional or national government who embrace the cause of the coca peasants, are frequently accused of being corrupt, radical, and on the payroll of the drug traffickers. Unfortunately, the more the United States and Peruvian governments criminalize the coca peasants and attempt to discredit the more moderate politicians who are sympathetic to their cause, the more radicalized the movement is likely to become and the more easily exploited it will be by extreme political groups and terrorist and criminal organizations.

A number of outside actors not especially friendly to the United States -Morales and Hugo Chávez, for example- also are trying to ally themselves with, exploit, or co-opt the Peruvian cocaleros. Morales, for one, has been trying to forge a pan-American movement of indigenous people and coca peasants of the Andes. Since eradication generates widespread antagonism toward the United States in the Andean region, and not simply among the peasants, it makes the population much more susceptible to anti-American populist appeals.

The war on drugs has been fought for 30 years, yet the United States has failed to persuade the majority of the people in the Andes that the effort is ultimately for their benefit. Instead, they overwhelmingly consider the drug problem to be one of demand -which the United States and Europe have failed to reduce. From their perspective, the coca peasants are only responding to the international market. As one prominent Peruvian journalist commented, "drugs are the one case where the United States is trying to impose moral reasoning on pure economic market forces."

\section{Drug war versus democracy}

Not only is one of the important means of establishing and sustaining democracy -civil society- inconvenient for the US-sponsored eradication effort, so is the very concept of democracy. An authoritarian regime is likely to be much more willing to militarily put down protesting groups and defeat armed peasants trying to 
Trouble Ahead: The Cocaleros of Peru/ 311

prevent the burning of their coca fields. The costs of such actions to the government are much greater in a democracy.

Living deep in the jungles and at the margins of legality, many of the peasants do not vote. Yet the institutionalization and increasing organization of their movement, as evinced in a 2003 march on Lima and the 2005 strikes across the country, have put serious pressure on the national government.

Succumbing to the temptation to use violence against the striking peasants, who paralyze cities and highways and cause major economic losses, might well be like pouring gasoline onto fire.

The war on drugs does not come into conflict with democracy simply at the level of national government. Increasingly, it also aggravates rifts between the center and the periphery. It is possible to win presidential elections while embracing the war on drugs. Indeed, it would be risky for any national candidate to publicly oppose the drug war. The United States likely would denounce such a candidate and threaten economic sanctions should he or she be elected. But it is more and more difficult for many Peruvian mayors or regional governments, such as in the departments of San Martín and Cajamarca, to get elected while supporting eradication.

The latest and most dramatic manifestation of how the war on drugs compounds rifts between Lima and rural areas occurred when the department of Cuzco -the least radical of all the coca-growing regions- legalized cultivation of all coca within the region. This act violated both national law and the international counterdrug treaties Peru has signed. The decision has been reversed. But the regional government finds itself again in a position of being unresponsive to one of the most pressing concerns of its constituents, as well as at odds with the national government. The episode is yet another demonstration of the tension between the war on drugs and the principles of accountability that the United States is trying to further in Latin America.

Desafíos, Bogotá (Colombia), (14): 304-317, semestre I de 2006 
312 / VANDA FELBAB-Brown

\section{Rising social strife}

Eradication is the most socially explosive counterdrug policy option. Premised on the notion that if illicit crops are wiped out, drugs will not enter the system, street prices for drugs will increase, and consumption will thus fall, eradication directly hurts poor peasants and pits the eradicating teams against them. Because Peru, unlike Colombia, does not allow aerial fumigation for environmental reasons and fear of even greater popular resentment, the teams that are sent to manually pull out the coca plants or burn the coca fields are vulnerable to armed resistance from coca-growing peasants. But even when the protection forces chase away the farmers or do not meet armed resistance, the coca farmers are hurt economically. They come to profoundly resent the government and are more likely to be co-opted by extremist groups.

Resistance by the coca peasants led the Peruvian government to adopt a "concerted and gradual" mode of eradication in June 2003. Under this program, each farmer was offered 100 kilograms of foodstuffs and a daily wage of 25 Peruvian soles (equivalent to $\$ 7.60$ ) for eradication work. The peasants were also promised a $\$ 180$ bonus per family to be gradually disbursed after progress in eradication. To each community that accepted eradication, the government also pledged to carry out two projects to improve social and economic infrastructure and two projects to improve productivity of legal crops. Under this program, however, eradication proceeded very slowly. Dissatisfied with the immediate lack of progress, the United States increased pressure on the Peruvian government to return to forced and faster eradication -without tedious negotiations with affected communities, and without first delivering compensation or alternative development assistance.

Yet forced eradication had failed to make a significant dent in coca cultivation in Peru before the adoption of the "concerted and gradual" program. In 2001, for example, 7,134 hectares of crops were eradicated, but an additional 9,700 hectares were planted (resulting in a total cultivation of 46,200 hectares).

Desafíos, Bogotá (Colombia), (14): 304-317, semestre I de 2006 
Trouble Ahead: The Cocaleros of Peru/ 313

Moreover, coca leaf prices in Peru have been climbing steadily since 1998, from 80 cents per kilogram of sun-dried coca leaf in 1997 to $\$ 2.80$ in 2004 .

Meanwhile, forced eradication in Colombia has reduced the area of coca cultivation in that country. It remains to be seen whether there will be any substantial and lasting decline of cocaine output from Colombia. However, because demand for cocaine remains unaffected, eradication in Colombia has increased the market opportunity and profitability for Peruvian peasants -the so-called balloon effect. While supply to the United States remains unaffected, "success" in Colombia is shifting production back to Bolivia and Peru.

Indeed, Peru registered a 14 percent increase in coca cultivation and a 23 percent increase in cocaine production between 2003 and 2004. Increased cultivation in Peru will generate greater pressure for eradication, which in turn will generate further clashes with the coca-growing peasants and increased social conflict.

\section{The interdiction alternative}

Some countries have chosen to use interdiction rather than eradication to deal with drug production. Unlike eradication, interdiction does not target coca peasants directly. It focuses instead on intercepting the smuggling of drugs and on the destruction of drug laboratories. Because of the vastness of the Amazon jungles, interdiction is frequently difficult. Yet, as Peru shows, interdiction can be effective. Under a US-sponsored operation named "Air Bridge" -conducted, with some suspensions, between 1991 and 2001planes taking off from Peru believed to be carrying coca paste and cocaine were intercepted.

Partly as a result, the market in Peru for coca leaf collapsed. The price of coca leaf fell steadily between 1991 and 1998, making it substantially less attractive for Peruvian peasants to grow coca. Coca leaf prices started to increase again in 1998, after the United States withdrew AWACs and P-3 aircrafts previously provided to the Peruvian Air Force for interdiction, a decision that significantly hampered

Desafíos, Bogotá (Colombia), (14): 304-317, semestre I de 2006 
314 / Vanda Felbab-Brown

interdiction efforts. Yet the area under cultivation in Peru continued to shrink until 2001 (while increasing rapidly in Colombia).

The aerial interdiction effort was discontinued altogether in 2001 when a small airplane belonging to the Association of Baptists for World Evangelism was shot down by mistake, killing an American missionary and her daughter. Although Washington instituted new procedures for monitoring anti-narcotics activities and placed additional restrictions on the "deadly force phase" of aerial interceptions, aerial interdiction has not been reinstituted in Peru. The Peruvian government is unable to carry out interdiction on its own, and even US financial aid for interdiction could make the US government liable for accidents. By contrast, eradication underwritten with US money and carried out by the Peruvian government does not entail any legal liability problems for the United States, even if it generates greater social strife in Peru.

Opponents of interdiction also maintain that aerial interdiction today in Peru would not be effective because smuggling routes have changed. Instead of planes taking off from the jungles to Colombia, coca paste and increasingly cocaine itself are carried by people from the Peruvian jungle to the coast and then smuggled by sea to Mexico and onward to the United States. Although sea interdiction could be adopted, the Peruvian government does not have the resources to undertake it on its own, and Washington prefers eradication.

\section{Turmoil ahead}

Peru is thus heading for further turmoil. Despite a history of tense relations with Washington on the issue of counternarcotics, Peru is unlikely to openly defy the United States, since the threat of repercussions -including economic sanctions- is considerable. Lima probably will accept social instability over an outright clash with Washington. What are the potential consequences of continuing social unrest in Peru? Despite the political and economic costs of instability, the government in Peru is unlikely to fall. A leftist populist government coming out of the cocalero movement -like the Morales phenomenon in Bolivia- is highly unlikely to emerge in the 
Trouble Ahead: The Cocaleros of Peru/ 315

short term. Much more likely is a further widening of the rift between Lima and the isolated drug-producing jungles in the east. Alienated by eradication, these regions will attempt to further separate themselves from the state, and, as in the Monzón Valley, try to push out the state's presence.

Peru as such will not become a failed state in the classic sense, but it will contain large and increasingly isolated regions of lawlessness, criminality, and drug cultivation. This will occur not simply because the state lacks the resources to be present, but because the people -several hundred thousand cocalero peasants- do not want it there.

Under US pressure, the Peruvian government may continue to try to carry out periodic eradication in these areas. It may even concede to aerial fumigation, since manual eradication is exceedingly difficult. But in the absence of firm control over the territory and of alternative means of subsistence for the population, drugs will become a growing problem. Instead of eliminating areas of lawlessness and state absence, eradication further isolates and radicalizes these regions.

\section{At cross-purposes}

Should the United States worry about a trend toward larger and more isolated areas of state absence in Peru and other countries in Latin America (for example, Bolivia, Ecuador, and Paraguay)? Despite warnings by US officials after 9-11 that parts of the region could become breeding grounds for Islamic terrorism, predictions that $\mathrm{Al}$ Qaeda and other Islamic terrorist groups might relocate to Latin America have not materialized. In fact, during a trip to Latin America in August 2005, Secretary of Defense Donald Rumsfeld backed off from warnings he had made a year before, pointing instead to "troublemaking" by leftist governments in Venezuela and Cuba.

It is possible, of course, that some Latin American guerrilla groups could choose to locate in these areas. Among such groups might be

Desafíos, Bogotá (Colombia), (14): 304-317, semestre I de 2006 
the Revolutionary Armed Forces of Colombia, whose members have made trips to Peru, or perhaps a reconstituted Shining Path or the Túpac Amaru Revolutionary Movement in Peru. A new Latin American terrorist group might emerge and choose to locate in these areas. But, although many guerrilla groups in the region have professed socialism and oppose US imperialism and capitalism, most have refrained from attacking US targets, with the exception of oil companies. Certainly, unlike Al Qaeda, they have not been motivated to attack the United States.

Paradoxically, the more aggressively the United States pursues eradication, the closer it will drive any such groups into an alliance with the drug dealers and the disaffected coca peasants and toward challenging US interests militarily. Eradication generates unnecessary enemies for the United States. It also complicates anti-terrorism intelligence gathering. Evidence from Peru in the 1980s shows that, when eradication was taking place, peasants refused to provide intelligence about the Shining Path to the government, and even took up arms against the state alongside the guerrillas. When eradication was halted, the peasants provided crucial intelligence on the guerrillas to the government.

A counternarcotics policy that ignores the social consequences of eradication further radicalizes and isolates areas of lawlessness and potential terrorist activity. It also strengthens the bond between disaffected social groups and guerrilla groups in these areas. Washington cannot continue to be blind to the fact that the three US interests of counterterrorism, counternarcotics, and democratization are not in harmony in its current policies toward Peru and elsewhere in Latin America. In fact, its counternarcotics policy works at cross-purposes with its counterterrorism and democratization objectives.

This does not mean the United States has to sacrifice its interest in combating drugs to further its counterterrorism and democratization objectives. If the United States recognizes the negative sideeffects 
Trouble Ahead: The Cocaleros of Peru/ 317

of its war on drugs, it can choose strategies that avoid or mitigate these effects, such as interdiction and committed, long-term, largescale alternative development assistance -or at least eradication accompanied by effective alternative development that is responsive to local needs. 